\title{
Assessment of Rescue Facilities and Personnel in the Ghanaian Underground Mines*
}

\author{
${ }^{1}$ S. Yenzanya and ${ }^{1} \mathrm{~N}$. Amegbey \\ ${ }^{1}$ University of Mines and Technology, P. O. Box 237, Tarkwa, Ghana
}

Yenzanya, S. and Amegbey N. (2018), "Assessment of Rescue Facilities and Personnel in Ghanaian Underground Mines", Ghana Mining Journal, Vol. 18, No. 1, pp. 56 - 64.

\begin{abstract}
Mine rescue was formally introduced in Ghana in the early 1960s by the then Ashanti Goldfields Company (AGC) and the practice has been adopted for most mineral projects in Ghana. Today, there are six large scale underground mines in Ghana with more than 100 permanent and volunteer rescue personnel trained and equipped for rescue operations. This paper sought to assess the qualification of rescue personnel and the adequacy of the rescue facilities in these mines. The paper adopted Gap Analysis method to assess the mines to see the extent to which they conform to the requirements in the Minerals and Mining (Health, Safety and Technical) Regulations of Ghana as well as international practices. From the study, Ghanaian mines practise mine-owned rescue systems and that all the mines have organised rescue teams on site. Using the Chirano Gold Mines Limited and Newmont Ahafo Mine as case studies, it was observed that rescue personnel in both mines conform to most of the regulations and have the basic response facilities and resources for rescue operations. It is recommended that mine regulators review some of the regulations on emergency response or provide guidelines and schedules to improve upon the rescue practices in Ghana.
\end{abstract}

Keywords: Mine Rescue, Ghanaian Regulations, Emergency Response, Rescue Personnel

\section{Introduction}

Mine rescue evolved with underground mining, although it was not well organised as done today. Rescue personnel were volunteers who were at the scene of the incident and made efforts to explore and save casualties. Over the years, mine rescue has undergone tremendous development and rescue personnel have moved from the use of complex techniques to simpler, safer and effective ways to explore and communicate during rescue operations (Anon., 2014).

The complexity of underground mines nowadays makes emergency preparedness a necessity as employees are exposed to wide degrees of risks such as fire, inundation, rockfall, air pollution from noxious gases, and poor ventilation. The situation becomes life-threatening, especially when the victims are far from the escapeway or safe havens.

To solve this, emergency preparedness has been incorporated into mine design and planning. In spite of this provision, there are still cases of mine emergency incidents reported each year in Ghana (Anon., 2015a); hence, mine operators and regulators have adopted different emergency response strategies to protect the lives of employees and also minimise the impact of accidents. This paper aims at assessing the measures put in place by the large scale mines to conform to the requirements of the Minerals and Mining Regulations (2012) of Ghana and also conform to best practices over the world. The study assessed the suitability and adequacy of rescue personnel, emergency response measures and facilities employed by the mines.

The structure and organisation of mine rescue differ across countries. Internationally, mine rescue organisations are grouped into four: state-run operations, mine-owned rescue, private company funded schemes, and co-operatives. In South Africa, India, USA, Canada, and Germany, the mine owners have the option to operate a mine rescue on the mine or hire a service provider (Mischo and Weyer, 2014; Lehnen et al., 2013).

A typical mine rescue operation in an irrespirable atmosphere consists of fifteen people: five on the primary response team, another five for back-up should the need arise and additional five in reserve status (standby) to provide support to the second team in the event that the team is deployed to assist the primary response team (Anon., 2008a; Lehnen et al., 2013). Germany, Canada and Australia require that a team has five members in addition to a captain (Lehnen et al., 2013; Anon., 2012b) while in India, Canada and South Africa, five people can form a team (Anon., 2008b; Anon., 1985). It is only in extreme cases, when lives are at stake and conditions are carefully weighed, that three or four persons may act as a team, but not without a backup (Anon., 2011).

Each country has set standards for the number of rescue personnel per mine. For a century now, the criteria used to determine the number of teams required for a mine have been done in proportion to the number of people employed underground. For example, in Ireland and Czech Republic, at least $2 \%$ and $5 \%$ respectively of the underground 
employees must be the mine rescue brigade. In the US and UK, at least two fully-equipped mine rescue teams have to be guaranteed per mine (Lehnen et al., 2013; Anon., 1977). In South Africa, a mine employing between 100 and 1100 requires at least one brigade, whereas in Ghana a mine employing between 150 and 500 people underground must have at least three brigades (Anon., 2008; Anon., 2012a).

\subsubsection{Qualifications of Rescue Personnel}

Several countries have similar qualification for rescue personnel. For example in Virginia, Ontario, one should be at least 18 years old (Anon., 2013), whereas in India, one should be 21 years old (Anon., 1985). Generally, the minimum age requirement of rescue team members in most countries are within 18-20 years and the person should not be more than 45 years old (Anon., 1977: Anon., 1985; Anon., 2012a).

USA and Canadian regulations require at least one year underground work experience for rescue recruits. The recruit at the end of training is expected to take oral or written exams including practical hands-on segment (Anon., 2006; Anon., 2012b).

Rescue personnel should be fit and medically certified each year for rescue activities. Periodic health examinations are obligatory for all rescue personnel and should be examined at least every 12 months. According to Kus (2013), the main reasons for issuing medical certificates confirming the person's ability for mine rescue services are: high blood pressure; high weight; negative result of Physical Work Capacity (PWC) test; arrhythmia; and negative result in a psychological examination.

\subsubsection{Training}

It is significant that rescue teams and supportive staff are trained to enable them take appropriate actions at the initial stages of a disaster. According to Anon. (1997), the work of a rescue team is unpredictable, requiring very short notice and usually physically and psychologically demanding. In Canada and USA, a member of a brigade is required to train for a minimum of 40 hours in each calendar year while in India members are required to train for 18 days in each year. In South Africa, USA and Australia, rescue training can be done underground or simulated. In USA, each rescuer must go underground at least once every six months with at least two hours under oxygen.

In South Africa, all rescuers are trained by one service provider hence rescue personnel have the same equipment and protocol. All rescue men go for training each quarter; specialised training and courses are also organised for rescue instructors and rescue personnel in the areas of heat tolerance, rope rescue, ambulance assistance training, control room procedures and others (Marx et al., 2008).

\subsubsection{Refuge Chambers}

Manufactured or portable refuge chambers are new facilities for underground mines that provide a minimum of 36 hours of breathable air, water, food, and other supplies for 4-30 trapped miners in the event of an emergency (Katherine et al., 2011; Anon., 2007). The use of portable refuge chambers in metalliferous mine has become common practice in Australia, USA, South Africa, New Zealand, Turkey, Indonesia and Ghana (Lehnen et al., 2013; Marx et al., 2008).

\subsection{Underground Mine Rescue in Ghana}

The first mine to establish a rescue brigade in Ghana was the then Ashanti Goldfields Company (AGC) now AngloGold Ashanti (AGA), Obuasi Mine. In the early 1960s, AGC trained some of its employees in mine rescue to save trapped miners and by the 1980s rescue training had become an integral part of the mine (Anon., 2015b). Today mine rescue, and in a broader context emergency management, has become an integral part of every mineral project in Ghana.

Currently, Ghana has fifteen large scale mines which are into either gold, manganese or bauxite production. Out of the fifteen, there are six underground mines which are all into gold production and operated by multinational companies. These underground mines are AngloGold Ashanti (AGA) Obuasi Mine, Newmont Ahafo Mine (NAM), Mensin Gold Mines (Bibiani Mine), Chirano Gold Mine Limited (CGML), Golden Star Resources - Wassa Mine and Prestea Underground Mine. They are distributed over the south-western part of Ghana, as shown in Fig. 1.

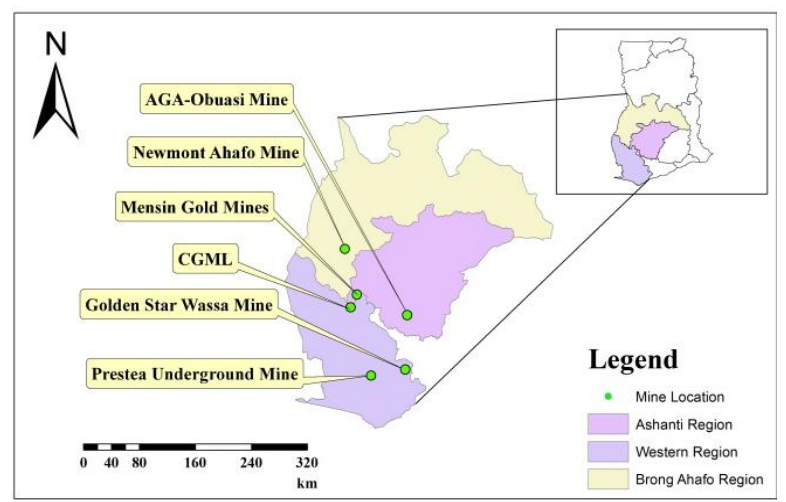

Fig. 1 Location of Underground Mines in Ghana 
At the time of this study, AGA Obuasi Mine, Bibiani Mine and Prestea Underground Mine were under care and maintenance while the Wassa Mine was at the development stage. CGML was in production while NAM had completed major underground developments and therefore preparing to start production. Consequently, CGML and NAM were used as case studies.

\section{Resources and Methods Used}

The data was collected from CGML and NAM between January 2015 and March 2016. The information on the rescue practices of the mines were obtained through interaction with rescue personnel, rescue instructors and inspectors of mines. The interaction was through questionnaires and personal interviews. The random sampling method was employed to select rescue personnel to answer the questionnaire. In all, 25 completed questionnaires were retrieved. The questionnaire sought to find out the following from the each rescue person:

(i) Level of education;

(ii) First aid certification;

(iii) Age;

(iv) Years of underground work experience before engagement in mine rescue services;

(v) Frequency of medical check-up; and

(vi) Training sessions.

In Ghana, the following requirements for rescue personnel are not document: level of education, first aid certification, age, years of underground work experience, frequency of medical check-up, types of training and basic rescue facilities. To determine the criteria for assessment of the practices in Ghanaian mines, the standard practices of South Africa, Australia and USA were reviewed since these countries have dedicated extensive time and resources into mine emergency management. The criteria for assessment used in this study were determined in consultation with inspectors of mines to ensure that they do not differ much from mine rescue traditions in Ghana.

To assess the rescue facilities, field visits were conducted to have firsthand information on the kind of facilities available to the rescue teams. Other sources of information include documents from the Mines.

Gap Analysis method was adopted for this study. The method allows the assessor to determine differences between what is practised and what should be practised. According to Jannetti (2012), the gap(s) can occur in knowledge or practice. The purpose is to compare standard practices to what is practised in order to establish the best practice. Conducting gap analysis helps to identify what one needs to put in place to bridge the gaps (Anon., $2015 b$ ). The method is widely used in marketing and also by the International Organisation for Standardisation.

\section{Results and Discussions}

\subsection{Organisation of Mine Rescue in Ghana}

Most Ghanaian underground mines started with surface mining and later developed underground; hence, some of the mines are concurrently operating surface mines and surface facilities such as Process Plant. AGA Obuasi Mine and NAM have one Emergency Rescue Team (ERT) in charge of both surface and underground operations while Prestea Mine, Wassa Mine, CGML and Bibiani Mine have separate ERTs. The number of persons employed underground as compared to the number of rescue personnel in the various mines has been shown in Fig. 2.

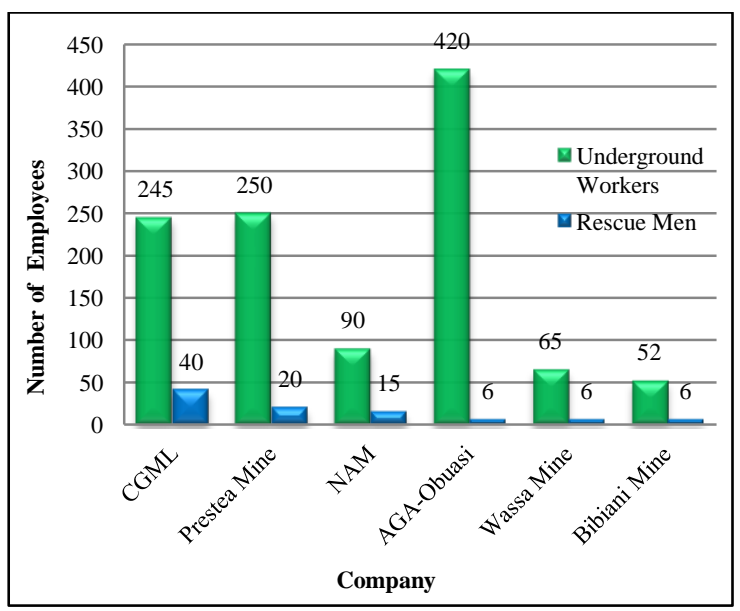

Fig. 2 Number of Rescue Personnel in the Mine

From Fig. 2, all the underground mines in Ghana have mine rescue brigade(s) and Ghana practices mine-owned rescue system. CGML has the highest number of rescue personnel and brigade (consist of at least 5 personnel) in Ghana. AGA-Obuasi Mine, Wassa Mine and Bibiani Mine have one (1) rescue brigade each while Prestea and NAM have three brigades each. At the time of this study, Obuasi, Wassa, Bibiani Mines had one rescue brigade each without a back-up. This was because the two mines were under care and maintenance while the Wassa Mine was at the development stage. It can be deduced from Fig. 2 that the percentage of underground employees to the rescue personnel in each mine are: CGML (16.3\%), Prestea Mine (8\%), NAM (16.7\%), AGA-Obuasi (1.4\%), Wassa Mine (9.2\%), and Bibiani Mine (11.5\%). 
Mine rescue in Ghana is organised and funded by the individual mines and this practice is referred to as mine-owned rescue system. The practice is favourable today because of the few and scattered nature of the underground mines (as seen in Fig. 1) with over $36 \mathrm{~km}$ travelling distance by road from each other.

\subsection{Rescue Capability of the Mines}

The ERTs in Ghana are charged with the responsibilities of responding to emergencies such as fire, flood, drowning in water, chemical spill, fall of ground, gas inhalation, etc. Other duties discharged include:

(i) Training of employees on how to use the breathing apparatus;

(ii) Conducting firefighting and evacuation drills;

(iii) Inspection of fire extinguishers;

(iv) Inspection and testing of all fire hydrants; and

(v) Administering first aid to casualties.

\subsection{Structure of Mine Rescue in Ghana}

Rescue personnel in Ghana are in two forms: permanent and volunteers. The permanent rescue personnel are employed solely for rescue jobs and are mostly available at the rescue stations while the volunteers are trained staff (certified) of the mines that are called during emergencies. The volunteers include blastmen, shiftbosses and mine captains. The total active rescuers in Ghana are 93 of whom 70 are volunteers and the rest are permanent. In the mines, emergency response departments work alongside the safety and medical team. Each rescue department is either headed by a rescue coordinator or a rescue or a rescue instructor. Currently, there are two (2) active rescue instructors in the country.

\subsection{Response Equipment}

The basic response equipment as provided by the Emergency Preparedness and Mines Rescue Guidelines of Australia for the emergency response teams was modified and used to assess the facilities available to the ERTs at CGML and NAM as shown in Table 1.

From Table 1, NAM has all the basic response equipment while CGML rescue teams lack flash proof clothing, extrication and pneumatic lifting equipment, hand operated hydraulic and Holmatro power hydraulics. It can be deduced that CGML has $79.2 \%$ of the basic response equipment for emergency response.
Table 1 Assessment of Basic Emergency Response Facilities at CGML and NAM

\begin{tabular}{|c|c|c|}
\hline Equipment & CGML & NAM \\
\hline \multicolumn{3}{|c|}{ Primary Response Equipment } \\
\hline Breathing apparatus (12) & $\checkmark$ & $\checkmark$ \\
\hline Escape apparatus & $\checkmark$ & $\checkmark$ \\
\hline Gas detection equipment & $\checkmark$ & $\checkmark$ \\
\hline Flash proof clothing & $x$ & $\checkmark$ \\
\hline First Aid & $\checkmark$ & $\checkmark$ \\
\hline Resuscitator & $\checkmark$ & $\checkmark$ \\
\hline Stretcher & $\checkmark$ & $\checkmark$ \\
\hline Rescue vehicle & $\checkmark$ & $\checkmark$ \\
\hline \multicolumn{3}{|c|}{ Surface Response Equipment } \\
\hline Basic hand tools and PPE & $\checkmark$ & $\checkmark$ \\
\hline $\begin{array}{l}\text { CABA (compressed air } \\
\text { breathing apparatus) }\end{array}$ & $\checkmark$ & $\checkmark$ \\
\hline $\begin{array}{l}\text { Synthetic slings, shackles, steel } \\
\text { wire rope }\end{array}$ & $\checkmark$ & $\checkmark$ \\
\hline $\begin{array}{l}\text { Extrication and pneumatic } \\
\text { lifting equipment }\end{array}$ & $x$ & $\checkmark$ \\
\hline First aid equipment & $\checkmark$ & $\checkmark$ \\
\hline Hand operated hydraulic & $x$ & $\checkmark$ \\
\hline $\begin{array}{l}\text { Holmatro power hydraulic } \\
\text { rescue equipment }\end{array}$ & $x$ & $\checkmark$ \\
\hline Lighting plant and generators & $\checkmark$ & $\checkmark$ \\
\hline Rescue roping equipment & $\checkmark$ & $\checkmark$ \\
\hline \multicolumn{3}{|c|}{ Secondary Response Equipment } \\
\hline Fire protection equipment & $\checkmark$ & $\checkmark$ \\
\hline $\begin{array}{l}\text { Firefighting (extinguishers, } \\
\text { suitable foam generators and } \\
\text { foam compounds) }\end{array}$ & $\checkmark$ & $\checkmark$ \\
\hline Lifelines & $\checkmark$ & $\checkmark$ \\
\hline Non sparking tools & $\checkmark$ & $\checkmark$ \\
\hline $\begin{array}{l}\text { PPE (kneepads, work gloves, } \\
\text { clothing, latex gloves, } \\
\text { respirators). }\end{array}$ & $\checkmark$ & $\checkmark$ \\
\hline Canoes for water rescue & $\checkmark$ & $\checkmark$ \\
\hline Thermal image camera & $x$ & $\checkmark$ \\
\hline
\end{tabular}

CGML and NAM also have other resources such as the following:

(i) Life jackets, compressed;

(ii) Hazmat suit;

(iii) Smoke chamber and obstacle room (see Fig. 3 for CGML) and Training gallery (see Fig. 4 for NAM);

(iv) First aid and medical services;

(v) Paramedic (NAM only);

(vi) Rescue trucks for underground use;

(vii) Water storage facilities;

(viii) Smoke chamber or gallery for simulated underground training;

(ix) Extra self-contained self-rescuers;

(x) Refuge chambers;

(xi) Sand bags;

(xii) Communication lines; 
(xiii) Safescape ladder tubes (see Fig. 5);

(xiv) Water tanks and hydrants with pumps;

(xv) Rescue stations; and

(xvi) Emergency coordination centres with incidents control rooms.

Besides the facilities provided above, the companies have other facilities such as pumps, cranes, earth moving machines, telehandlers which are used for mining and processing purposes but can also be given out for rescue operation when needed.

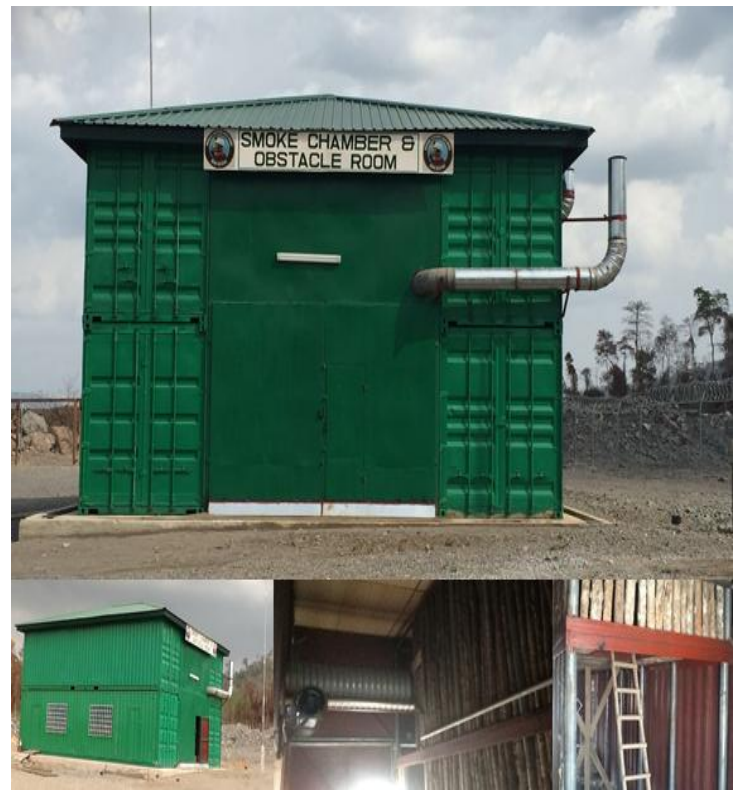

Fig. 3 Smoke Chamber and Obstacle Room at CGML

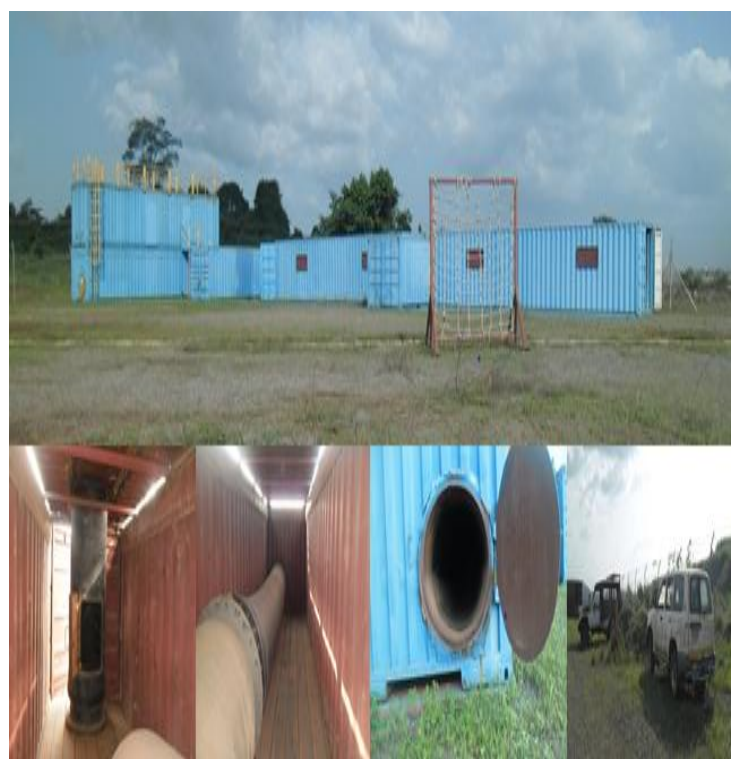

Fig. 4 Training Gallery at NAM

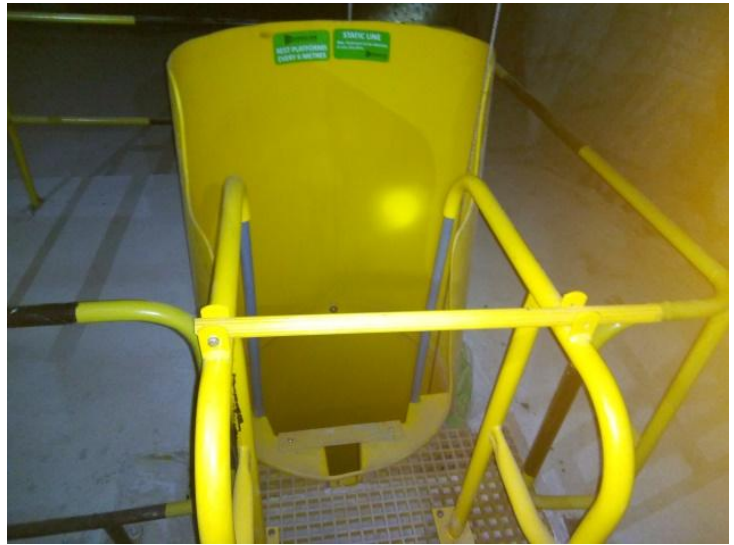

Fig. 5 Safescape Ladder Tube at CGML

From the facilities provided in this section, it can be said that the two mines have the basic resources and facilities for rescue operations.

Most of these facilities can also be found in most underground mines. It is only the Wassa Mine which does not have the training gallery or adit and this is because it is at the development stage.

\subsection{Qualifications of Rescue Personnel}

Survey was conducted at CGML and NAM to see the extent to which they conform to basic requirements such as ability to read and write, first aid certification, age, underground work experience and attendance to medical check-up and educational background.

\subsubsection{Level of Education}

The educational level was sought to check whether the rescue personnel have the requisite educational background to enable them read and write. The classification was Middle School Leaving certificate, Junior Secondary School certificate, Senior Secondary School (SSS) certificate, Technical and Vocational School certificate, Ordinary Level (O'Level) certificate, Higher National Diploma (HND), and Degree. The results are shown in Figs. 6 and 7.

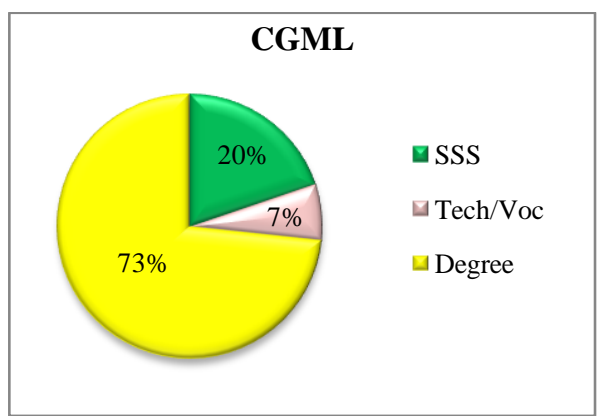

Fig. 6 Educational Level of Rescue Personnel CGML 


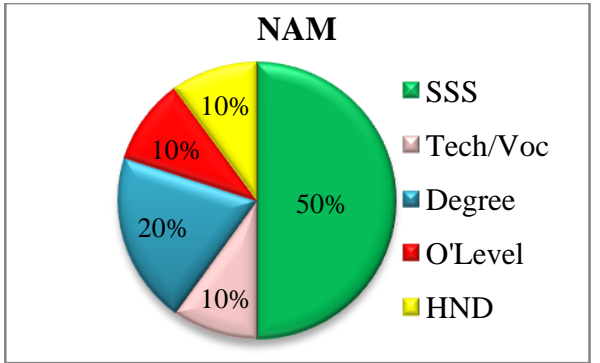

Fig. 7 Educational Level of Rescue Personnel at NAM

From Fig. 6, it is realised that at CGML the least educational level of the rescue personnel is Technical/Vocational School with the highest being a Degree. The high number $(73 \%)$ of degree holders at CGML is attributed to the presence of volunteers who range from shiftbosses to managers and have degrees in mining or allied discipline.

From Fig. 7, most of the rescue personnel at NAM are within the Senior Secondary School (SSS) category with the least being O'Level. It was noticed that most of the permanent rescue personnel are within SSS level. This suggests that degree holders are not usually employed directly into emergency response and rescue departments. From the results, it can be deduced that all the rescue personnel can read and write.

\subsubsection{Basic First Aid Certification}

A survey was conducted to check whether the rescue personnel have first aid certificates and the response from both mines indicated that all the rescue personnel have first aid certificates from the St. John Ambulance.

\subsubsection{Age}

The ages of the rescue personnel were sought and the results are as shown in Figs. 8 and 9.

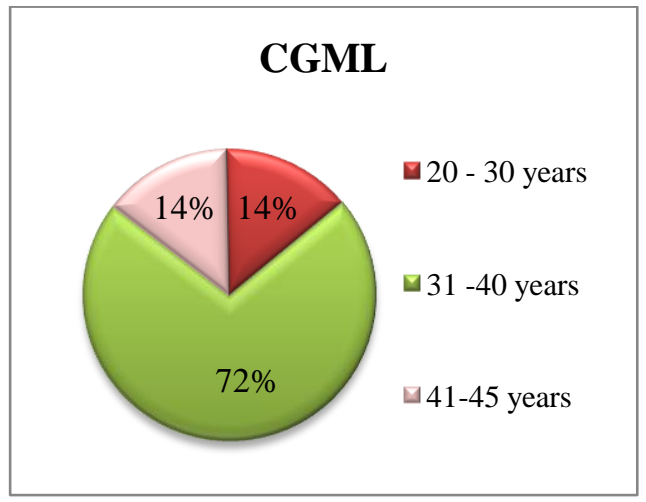

Fig. 8 Ages of Rescue Personnel at CGML

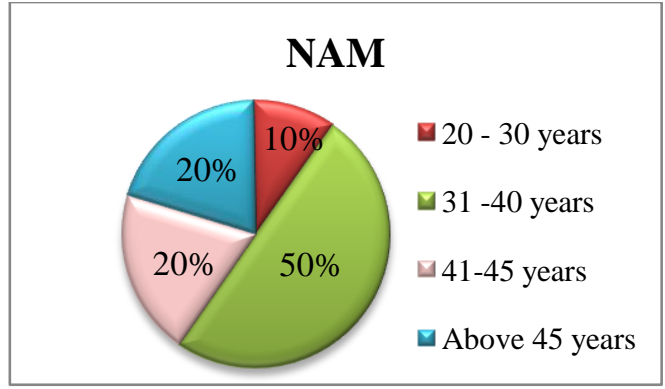

Fig. 9 Ages of Rescue Personnel at NAM

Fig. 8 shows that all rescue personnel at CGML are within the acceptable age limits (within 20 and 45 years). At NAM (Fig. 9), none of the rescue personnel are below 20 years. The mine has $80 \%$ of the rescue personnel to be less than 45 years while $20 \%$ of them are above 45 years which is above the required years to be active in rescue operations. It can be deduced from Fig. 8 and Fig. 9 that, 92\% of the rescue personnel studied are within the acceptable age limits.

\subsubsection{Underground Work Experience}

The number of years the rescue personnel worked underground before their appointment into mine rescue were sought in both mines and the results are in Fig. 10 and Fig. 11.

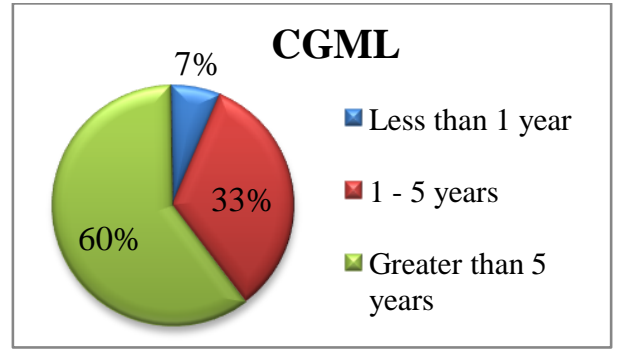

Fig. 10 Previous Underground Work Experiences of the Rescue Personnel at CGML

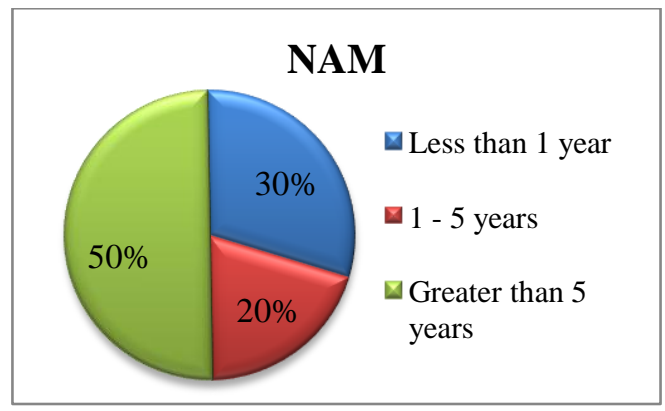

Fig. 11 Previous Underground Work Experiences of the Rescue Personnel at NAM

At CGML (Fig. 10), 93\% of the rescue personnel have more than 1 year underground work 
experience while $7 \%$ have less than 1 year underground work experience. Those with less than 1 year underground work experience are people employed because of their stature, skills in swimming among others. At NAM (Fig. 11), 70\% of the rescue personnel have more than 1 year underground work experience while $30 \%$ have less than 1 year underground work experience. This is because the mine maintained the surface rescue personnel during the transition from surface mining to underground mining.

From the practices of both mines, it is noticed that underground work experience as a requirement for rescue personnel may be exempted by the Chief Inspector of Mines so as to fall in line with the practices of South Africa, Australia and USA.

\subsubsection{Medical Check-up}

A survey was conducted to find out the frequency at which rescue personnel go for medical check-up and the results are illustrated in Figs. 12 and 13.

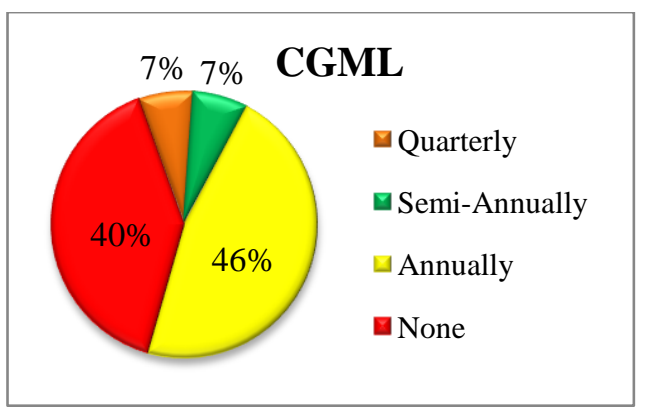

Fig. 12 Medical Check-up by Rescue Personnel at CGML

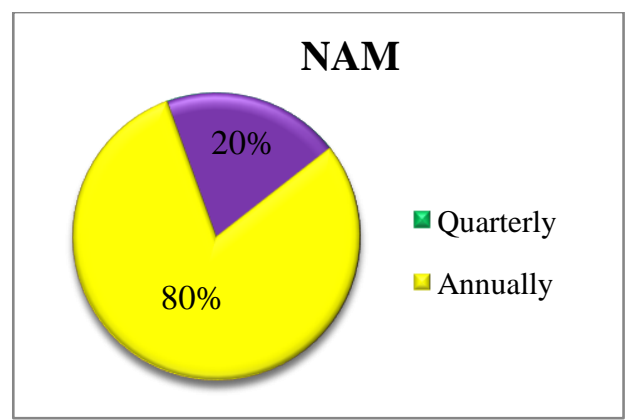

Fig. 13 Medical Check-up by Rescue Personnel at NAM

From Fig. 12 shows that at CGML, 46\%, 7\%, and $7 \%$ of the rescue personnel attend medical checkup annually, semi-annually, and quarterly, respecttively. Also at CGML, $40 \%$ of the rescue personnel do not attend medical check-up at all. This is because some of the rescue personnel do not spend all their annual leave days at one time but rather in portions. The policies of the mines are such that one goes for medical check-up when one spends more than two continuous weeks at home. It was noticed that those who do not go for medical check-up were the volunteers who may not spend all the annual leave days at a time due to responsibilities assigned to them.

From Fig. 13, $80 \%$ and $20 \%$ of the rescue personnel of NAM go for medical check-up annually and quarterly, respectively thus, all the rescue personnel at NAM go for medical check-up at least once every year.

It can be deduced that the permanent rescue personnel are more likely to go for medical checkup regularly compared to volunteers.

\subsubsection{Training by Brigade Personnel}

A survey was conducted to assess how often the rescue personnel participate in training call-outs. The results are summarised in Fig. 14.

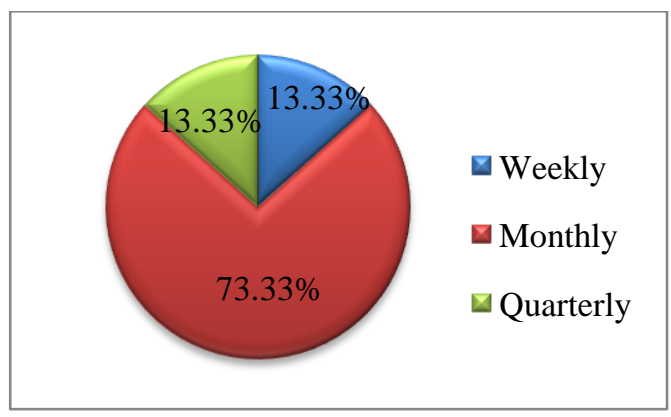

Fig. 14 Training Call-Out at CGML

From Fig. 14, 73\%, 13.33\%, and $13.33 \%$ of rescue personnel at CGML attend monthly, weekly and quarterly training sessions respectively. The Ghana regulations require 12 training sessions for each rescuer per year and this means, a rescuer must attend at least one training session every month. The $13.33 \%$ weekly training by the rescue personnel can be attributed to weekly call-outs of the permanent rescue team while the other $13.33 \%$ quarterly training can be attributed to sparse participation of the volunteers who are supervisors and managers and who are mostly on job assignment.

The same survey was conducted for NAM rescue team and the result indicates that all the rescue personnel attend training at least once a month. In all, most of the rescue personnel participate in training at least once each month. On average, the ERTs from both mines train for a minimum of 4 hours each session and this gives more than 40 hours each year as required by USA and Canadian regulations. 


\section{Conclusions and Recommendations}

\subsection{Conclusions}

The following observations were made regarding mine rescue:

(i) The number of rescue teams required per mine differs across countries. Literature does not provide any basis for the differences.

(ii) There is no documented qualification for rescue personnel, rescue instructors, rescue coordinators, and rescue attendants in Ghana.

(iii) There is no documented minimum requirement for mine rescue stations and emergency coordination centres in Ghana however, mines inspectors provide directives when necessary.

It is therefore concluded that:

(i) Ghanaian Mines practise mine-owned rescue system;

(ii) Rescue personnel in Ghanaian mines have the qualification and the basic facilities for rescue operations; and

(iii) The mines comply with the emergency response and rescue regulations of Ghana and also best practices in countries like South Africa, Canada, USA and Australia although there is room for improvement.

\subsection{Recommendations}

For best practice, the following should be:

(i) Ghana standard for mine rescue should be spelt out to serve as a guide to everybody.

(ii) Frequency of rescuers to medical check-ups should be encouraged since some $(40 \%)$ of the volunteer rescuers do go for medical check-up.

(iii) Rescue personnel in Ghana should be medically certified and copies of certification should be sent to the Chief Inspector of Mines.

(iv) There should be penalties for volunteers who fail to meet training requirements for a year.

(v) There should be a memorandum of understanding among the mines to assist each other with rescue teams and other resources when needed.

(vi) L. I. 2182 should be revised to include minimum requirement for mine rescue stations, emergency coordination centre, breathing apparatus and self-contained selfrescuers. Also, it should include the qualification of rescue personnel, rescue instructors, rescue coordinators, and rescue attendants.

(vii) There should be a national mine rescue body or committee to facilitate joint rescue training programmes, rescue competitions and the continuous improvement of emergency response.

(viii) Currently, AGA-Obuasi, CGML and NAM mines are using manufactured refuge chambers hence, it is imperative that the regulations address the requirements and use of the facility.

\section{References}

Anon. (1977), "Mine Rescue Teams for Underground Metal and Non-metal Mines", 30 CFR Part 49 Subpart A, Federal Mine Safety and Health Act of 1977, www.law.cornell.edu/cfr/text/30/part-49/subpart-A,

Accessed: June 10, 2015.

Anon. (1985), "The Mines Rescue Rules", Directorate General of Mine Safety, India, www.dgms.net/Mines\%20Rescue\%20Rules.pdf, Accessed: June 20, 2015.

Anon. (2006), "Mine Rescue Handbook: Emergency Response Procedures, Practices and Responsibilities", www.nma.org/pdf/ 010507_safety_handbook.pdf, Accessed: June 20, 2015.

Anon. (2007), "Summary of U. S. Mines with Refuge Chamber", National Technology Transfer Centre, National Institute for Occupational Health and Safety, USA, 82 pp.

Anon. (2008a), "Responding to a Mine Emergency - Training Responsible Persons at Underground Coal Mines" Instruction Guide Series 110, U.S. Department of Labour, Mine Safety and Health Administration, $97 \mathrm{pp}$.

Anon. (2008b), "Rescue, First Aid and Emergency Preparedness and Response", Mine Schedule, Health and Safety Act 1996, No. 29, South Africa, 5 pp.

Anon. (2011), "Emergency Preparedness and Mines Rescue Guidelines", Mines Rescue Pty Limited, Australia, $6 \mathrm{pp}$.

Anon. (2012a), "Minerals and Mining Regulations (Health, Safety and Technical) Regulation" Assembly Press, Accra, Ghana, 519 pp.

Anon. (2012b) "State Of West Virginia", Certification Policy Manual, Office of Miner's Health, Safety and Training, Virginia, 64 pp.

Anon. (2013), "Certification Policy Manual", Miner's Health, Safety and Training, West Virginia, USA, 64 pp.

Anon. (2014), "History of Mine Rescue" United States Department of Labour, www.msha.gov/TRAINING/LIBRARY/historyofminerescue/pag e12.asp, Accessed: March 3, 2015. 
Anon. (2015a), "History of Mine Rescue in Ghana", Unpublished Mine Document, AngloGold Ashanti - Obuasi Mine, Obuasi, 2 pp.

Anon. (2015a), "Mine Accidents in Ghana", Unpublished Records from the Inspectorate Division, Minerals Commission, Ghana, 2 pp.

Jannetti, A. J. (2012), "Incorporating a Needs Assessment and Gap Analysis into the Educational Design", Pitman, New Jersey, 2 pp.

Katherine, A. M., Westerman, C. Y. K. and Kathleen, M. K. (2011), "Underground Mine Refuge Chamber Expectations Training: Program Development and Evaluation", National Institute for Occupational Safety and Health, Pittsburgh, USA, 9 pp.

Kuś, M. (2013), "Methodology of Medical and Psychological Examinations - Criteria and Rules of Work Ability Assessment in Mine Rescue Services", International Mine Rescue Body, www.minerescue.org/ conferences/2013_niagara_falls.htm, Accessed: October 16, 2015.

Lehnen, F., Martens, P. N. and Rattmann, L. (2013), "Evaluation of European Mine Rescue and Its Need for Internationalisation", $4^{\text {th }}$ International Symposium on Mineral Resources and Mine Development, RWTH Aachen, International Mining Symposia (AIMS), Vol. 12, VGE-Verlag GmbH, Essen, pp. 175-186.

Marx, W. M., Van Zyl, F. J., Doyle, B. A. and Mc Intyre, R. H. (2008), "Final Report: Review of Best Practices for Escape and Rescue from Underground Coal Mines in South Africa", www.cdc.gov/niosh/docket/archive /pdfs/NIOSH-154/0154-050108-marx.pdf,

Accessed: November 7, 2015.

Mischo, H. and Weyer, J. (2014), "Reorganisation of Mine Rescue Services Scheme in Central Europe", SME Annual Meeting, Salt Lake City, Utah, 6 pp.

Ruberg, L., Moore, D. and McFarland, L. (2013), "Inventory of U.S. Mine Rescue Training Facility that Support Coal Mine Rescue Training", National Institute for Occupational Safety and Health, USA, 30 pp.

\section{Authors}

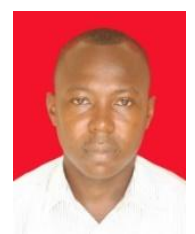

Sylvester Yenzanya is an Assistant Lecturer at the University of Mines And Technology (UMaT), Tarkwa, Ghana. He holds a BSc (Honours) and MPhil in Mining Engineering from UMaT. His research interests are in Mine Ventilation, Environmental Management, Occupational Health and Safety, and Emergency Management.

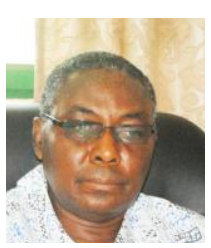

Newton Amegbey is a Professor of Mining Engineering at University of Mines and Technology (UMaT), Tarkwa, Ghana. He hold a Dr-Ing from Technical University of Berlin, West Germany. He is a member of Mine Ventilation Society for South Africa, German Society of Mining and Metallurgy and Society for Mining, Metallurgy and Exploration, USA. His research areas are Mine Ventilation and Safety Engineering/Human Factors, Mining Regulations, and Environmental Management. 